\title{
肝疾患における血清アルコール 脱水素酵素の臨床的意義*
}

$\begin{array}{llllll}\text { 滝野 } & \text { 辰郎 } & \text { 結城 } & \text { 武彦 } & \text { 川村 } & \text { 治雄 } \\ \text { 豊田 } & \text { 栄一 } & \text { 坂中 } & \text { 俊男 } & \text { 高森 } & \text { 成之 } \\ \text { 高橋 } & \text { 示人 } & \text { 金綱 } & \text { 隆弘 } & \text { 増田 } & \text { 正典 }{ }^{* *}\end{array}$

要 旨: Serum Alcohol Dehydrogenase (S-ADH) を肝疾患 108例, 非肝疾患41例，アルコール多 飲者17例について臨床的意義を検討した.S-ADH は正常者では活性は低く，非肝疾患です低値 であった，急性肝炎では S-ADH は GOT, GPT と平行して動くが，流行性肝炎においてはGOT， GPT より早く正常化し，輸血後肝炎では持続的上昇を示す例が多かった． 慢性肝炎活動型では 非活動型に比し有意に S-ADH が高く，持続的高値を示す例が多く両者の鑑別の補助的方法の一 つとして有用と思われた. 脂肪肝, 前硬変, 肝硬変および肝腫汮, アルュール多飲者では大多数 の症例で S-ADH は正常値を示し, 閉塞性黄疸では肝内性および肝外性胆汁うっ滞とすに S-ADH の持続上昇する症例は少なかった. S-ADH は肝機能では, GOT, GPT と P<0.001で有意の相関 があり，S-Fe とは相関の傾向が見られた．また肝組織所見でも肝細胞壊死と0.05<P<0.1で 相関の傾向が見られた. 今回の患者血清の S-ADH はすべて Atypical ADH を示した.

索引用語 : アルュール脱水素酵素 慢性肝炎活動型 アルコール多飲者 肝細胞壊死

\section{はじめに}

Alcohol Dehydrogenase (ADH) は主に肝細胞の上清部 分に存在し、フルュール代謝に関与する ${ }^{1,2)}$ ，本酵素の 臟器分布は大部分肝に存在し, 少量が胃, 晹, 腎, 網 膜，㜆に分布するといわれ 中K本酵素が逸脱し，血清 ADH (S-ADH) の上昇がみ られる.

今回我↔は各種肝疾患における血清 ADH の測定を行 ない，その臨床的意義について検討する機会を得たので その結果をここに報告する.

\section{対象およひ方法}

\section{1. 対 象}

当科および関連病院に入院中または外来通院の患者で 肝生検, 腹腔鏡, 剖検または臨床経過により診断の確定 した肝疾患 108例（検体数：356）および非肝疾患41例

* 本論文の諭旨は第 8 回日本肝葴学会総会におい て器表した。

** 京都府立医科大学第三内科 〈受付日 49 年 6 日 5 日>
（検体数: 67）,アルコール多飲者17例（検体数：47）て ある.

内わけは肝疾患として Table 1 に示すごとくであり， 非肝疾患として胃潰瘍，胃癌を含む胃疾患，潰瘍性大腸 炎，大腸ポリープ，大腸癌，クローン氏病を含む腸疾


癌を含む膵疾患, 胆石, 胆栾炎の胆道障害である。フル コール多飲者は1日 3 合, フルコール量にして80 g, 2 年以上の飲酒歴のある者とした"s.

コントロールは日赤血夜センターでの供血者のらち HB抗原，Wa 反応，GPT の異常でない87例を用いた。

- 2. 方 法 (Thble 2)

S-ADH の測定忠者の空腹時血清を用い， E. Mezey の変法 ${ }^{15}$ を用いた. すなわら島津記録計付 UV-200分光 光度計を用い, 基質にエタノール, 補酵素に NAD を用 い, 5 分間の酵素度応により生成される NADH を 340 $\mathrm{m} \mu$, 至適 $\mathrm{pH}: 8.5,25^{\circ} \mathrm{C}$ で測定し, S-ADH の活性の 1 単位 (U) を血清 $1 \mathrm{~m} l, 1$ 時間につき $0.001 \mu$ mole NADH とした. 
Table 1.

\begin{tabular}{|c|c|}
\hline Hepatic Diseases & No. of Patients \\
\hline Infectious Hepatitis & 19 \\
\hline Post-transfusion Hepatitis & 15 \\
\hline Fatty Liver & 8 \\
\hline Chronic Hepatitis & 38 \\
\hline Active Type & 17 \\
\hline Inactive Type & 21 \\
\hline Precirrhosis & 7 \\
\hline Cirrhosis & 11 \\
\hline Liver Tumor & 7 \\
\hline Hepatoma & 2 \\
\hline Metastatic & 4 \\
\hline Cholangioma & 1 \\
\hline \multirow[t]{2}{*}{ Drug-induced Hepatitis } & 3 \\
\hline & 108 \\
\hline Non Hepatic Diseases & No. of Patients \\
\hline Gastric Disease & 13 \\
\hline Ulcer & 8 \\
\hline Carcinoma & 5 \\
\hline $\begin{array}{l}\text { Intestinal Disease } \\
\quad \text { (Ulcerative Colitis, Polyp etc. ) }\end{array}$ & 10 \\
\hline Renal Disease & 2 \\
\hline Pancreatic Disease & 5 \\
\hline Biliary Disorder & 11 \\
\hline Total & 41 \\
\hline Alcoholics & 17 \\
\hline
\end{tabular}

Table 2.

Determination Method of S-ADH (By E. Mezey) The S-ADH activity was determined in a Hitachi UV-200 Spectrometer with recorder at $25^{\circ} \mathrm{C}$ for 5 $\min$.

\begin{tabular}{lcc}
\hline & Tested $(\mathrm{m} l)$ & Blank $(\mathrm{m} l)$ \\
0.1 M Glycine-NaOH Buffer & 0.21 & 0.21 \\
0.025 M NAD & 0.02 & 0.02 \\
Serum & 0.10 & 0.10 \\
Distilled water & 0.27 & 0.27 \\
0.5 M Ethanol & 0.02 & - \\
\hline
\end{tabular}

The Assay condition: The wave length: $340 \mathrm{~m} \mu$ The optical pH: 8.5

$1 \mathrm{U}=0.001 \mathrm{~mole} / \mathrm{m} / \mathrm{hr}$. Normal range : $0 \sim 22 \mathrm{U}$

$$
\text { 成 績 }
$$

1. S-ADH 活性の正常值 (Fig. 1)

健康供血者 87 名の血清 ADH 活性の平均值士S.D. は 3.7士8.9Uであり，M+2 SDをとり正常值を 0 から22

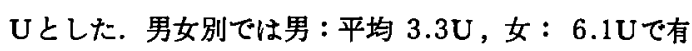
意差はなかった。

\section{2. 各程訮疾患の S-ADH 活性}

各症例の最高値をブロットしてみると。

a) 急性肝炎では（Fig. 1) に示すごとく，流行性肝炎 急性期 (発症後 $1 \sim 3$ 週) 平均值 : $119.4 \mathrm{U}$, 輸血後

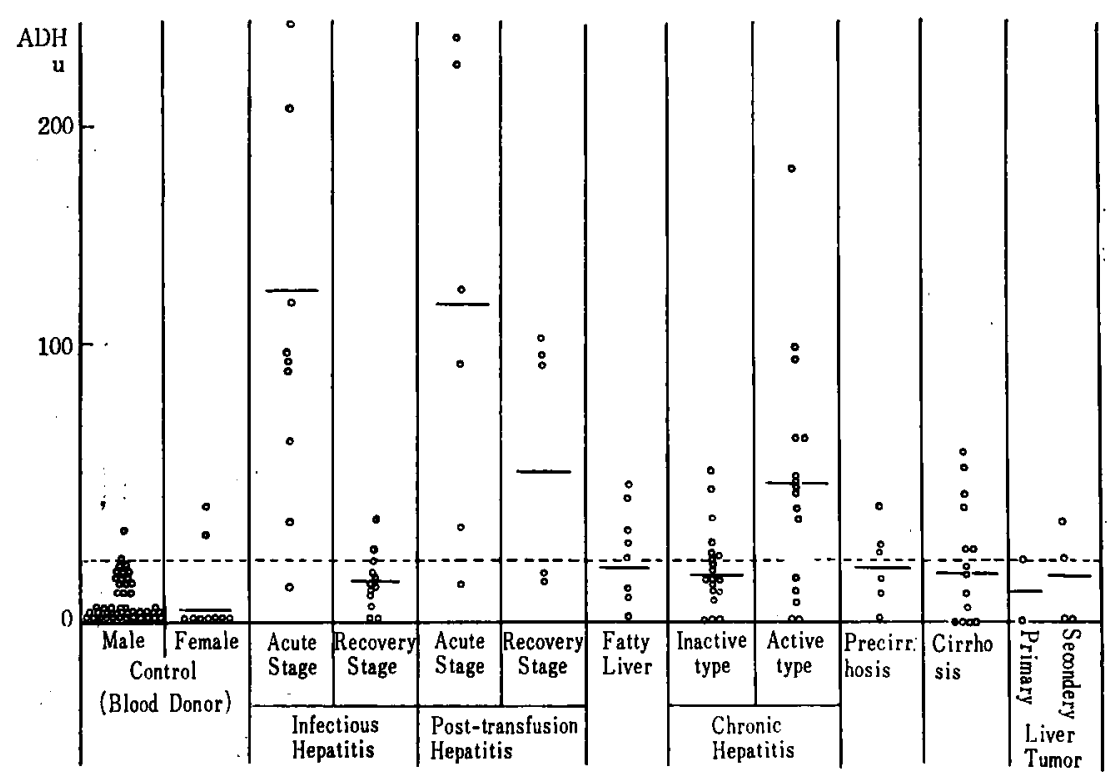

Fig. 1. S-ADH in Hepatic Diseases 
肝炎急性期 平均値：114.2Uとともに高値であり， 流行性肝炎回復期（ 7 12週）では平均値：14.0Uと 正常化したが, 輸血後肝炎回復期では平均値 : $53.1 \mathrm{U}$ と中等度上昇を示した。

b) 慢性肝炎では非活動型 平均値 : $16.8 \mathrm{U}$, 活動型 平均値：48.9U と後者が有意に高値を示した.

c) 脂肪肝 (平均値 : $15.3 \mathrm{U}$ ), 前硬変 (平均值 : 14.2 U), 肝硬変 (平均値 : 13.5U) では平均値は正常範 囲にあった。

d) 肝腫瘍：肝癌を原発性，続発性に分けて見たが，原

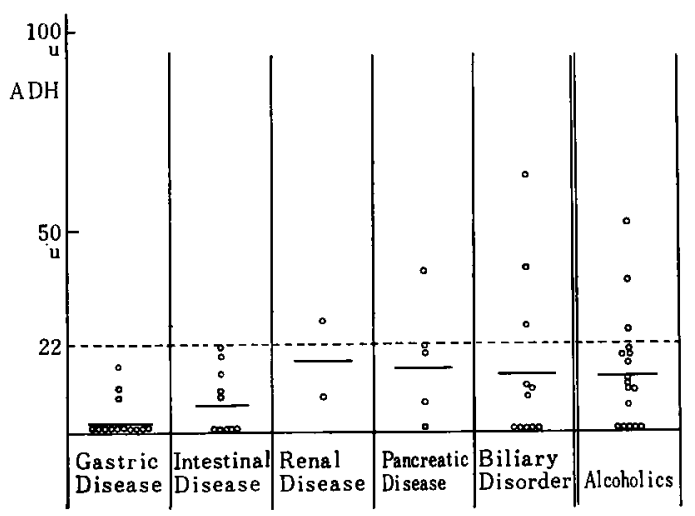

Fig. 2. S-ADH in Non Hepatic Diseases
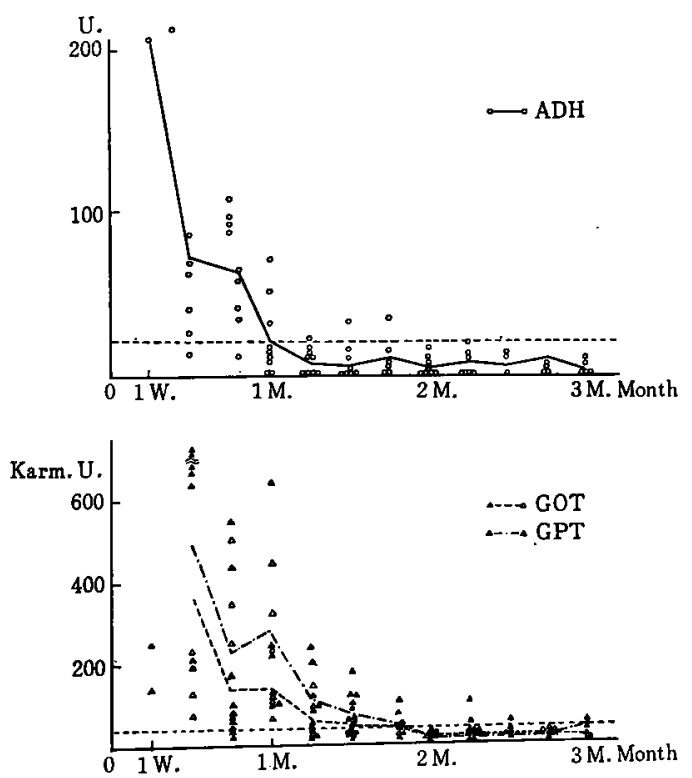

Fig. 3. ADH, GOT \& GPT Alteration in Infectious Hepatitis
発性（平均值 : $10.9 \mathrm{U}$ ), 続発性（平均値 : 7.6U) と あ著明な上昇が見られず，正常值を示するのが多か 吠.

e）韭肝疾患では胃，腸，脺，胆道疾患の大多数で平均 值は正常範囲内にあり，S-ADH 活性の上昇は肝疾患 に特異的であると考えられた（Fig. 2)．

f）フルコール多飲者. 組織所見は正常 6 例, 軽度障害 型10例, 肝硬変 1 例であったが, S-ADH 活性の上昇 を示す例は少なかった。

3. 肝疾患における S-ADH の経過

急性肝炎で GOT, GPT との関連を見ると, 流行性肝
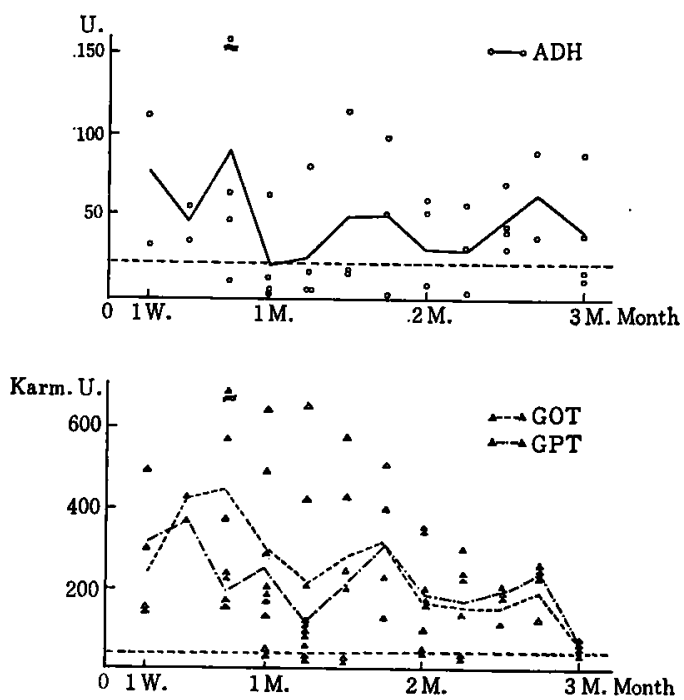

Fig. 4. ADH, GOT \& GPT Alteration in Posttransfusion Hepatitis

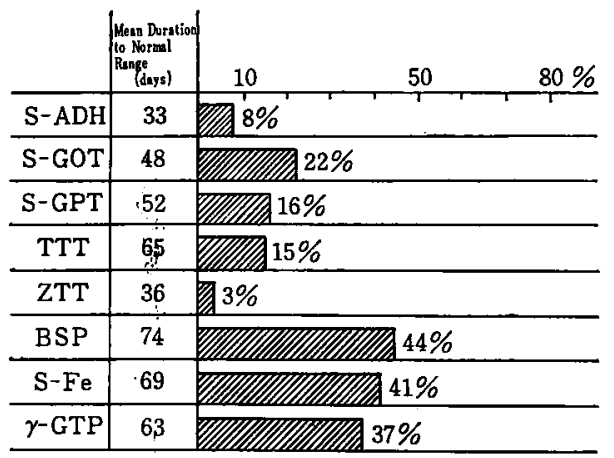

Fig. 5. Abnormal Liver Function Tests in Recovery Stage of Infectious Hepatitis

(7 weeks from onset) 
炎では急性期に高値を示し，GOT，GPT に平行して 動くが，平均正常化日数は S-ADH 33日，GOT 48日， GPT 52日で，S-ADH はより早く正常化した（Fig. 3). 輸血後肝炎でる S-ADH は GOT, GPT に平行して持続 的に上昇し，要延する例が多かった（Fig. 4).

流行性肝炎回復期（発症後 7 週）飞おける各種肝機能

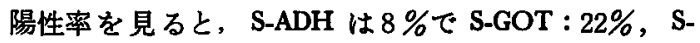
GPT $16 \%$ ，BSP $44 \%$ と陽性率が高值を示し，平均正常 化日数は S-ADH 33日で S-GOT 48日，S-GPT 52日， BSP 74日より明らかに早かった（Fig. 5)．

慢性肝炎を活動型と非活動型て S-ADH の持続的上昇 群，一過性上昇群，正常群に分けて見ると，活動型では $\chi^{2}=6.1010,0.02<P<0.05 て ゙$ ，持続的上昇する例が多 い㑯向を示した (Fig. 6).

慢性肝炎非活動型と活動型を肝機能の異常頻度で見る と, S-ADH は非活動型で20\%, 活動型で67\%の異常を 示し，陽性率の差では GOT, GPT 上り著明で（0.05く $\mathrm{P}<0.1)$, TTT 同様有意の傾向があり, 活動型, 非活 動型の管別の補助的方法になると思われた (Fig. 7).

流行传肝资を黄㡺の有無により S-ADH 活性を比較し たが，両者の間に有意差はなかった（Fig. 8 ）.

4. 閉塞性黄疸と S-ADH 活性 (Fig. 9)

\begin{tabular}{|c|c|c|c|c|}
\hline & $\begin{array}{c}\text { Average of } \\
\text { S-ADH }\end{array}$ & $\begin{array}{c}\text { cont inuous } \\
\text { elevation }\end{array}$ & $\mid \begin{array}{l}\text { transient } \\
\text { elevation }\end{array}$ & normal \\
\hline $\begin{array}{c}\text { inactive } \\
\text { type }\end{array}$ & $16.8 \pm 4.9$ & 1 & 2 & 9 \\
\hline $\begin{array}{r}\text { active } \\
\text { type }\end{array}$ & $48.9 \pm 16.2$ & 5 & 5 & 3 \\
\hline
\end{tabular}

Fig. 6. S-ADH in Chronic Hepatitis

\begin{tabular}{|c|c|c|}
\hline & Inactive Type & Active Type \\
\hline $\mathrm{ADH}^{*}$ & TI & TIIIIIIII) \\
\hline GOT & TP & $\mathbb{E}$ \\
\hline GPT & & \\
\hline TTT* & Th & पाश्या? \\
\hline $\mathrm{ZTT}$ & पIII & पागय \\
\hline$\gamma-\mathrm{Gl}$ & प110111 & 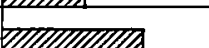 \\
\hline RA & VIII) & ग110119 \\
\hline & $\frac{1}{50 \%}$ & $\begin{array}{r}50 \% \\
\times 0.05<p\end{array}$ \\
\hline
\end{tabular}

Fig. 7. Abnormal Liver Function Test in Inactive and Active Type of Chronic Hepatitis

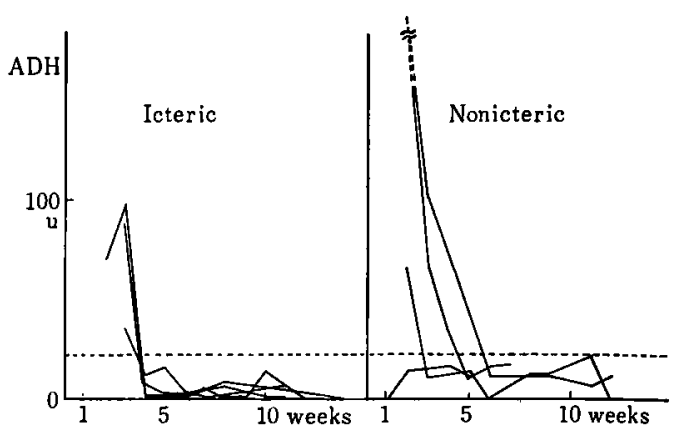

Fig. 8. S-ADH in Infectious Hepatitis

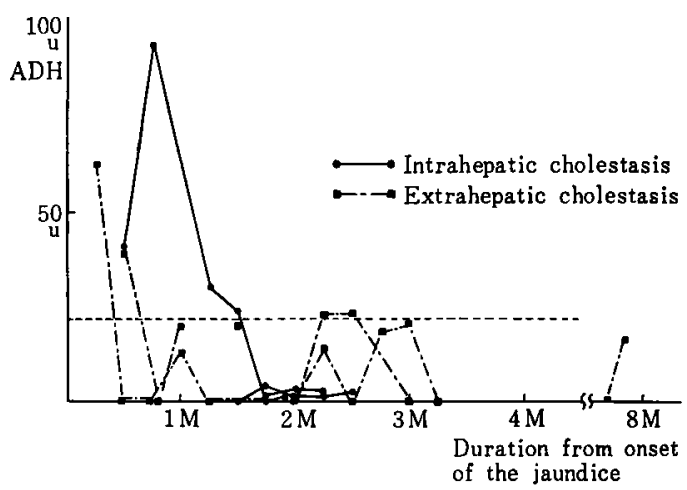

Fig. 9. S-ADH in Obstructive Jaundice

Table 3. S-ADH Correlation to Liver Function Tests

\begin{tabular}{|c|c|c|c|}
\hline T.B. & $\begin{array}{r}r=0.077 \\
\quad P>0.1\end{array}$ & T.P. & $\begin{aligned} r & =0.110 \\
& P>0.1\end{aligned}$ \\
\hline B.S.P. & $\begin{array}{c}\mathbf{r}=-0.0241 \\
\mathbf{P}>0.1\end{array}$ & $\gamma$-Gl. & $\begin{array}{r}\mathbf{r}=-0.06 \\
\mathbf{P}>0.1\end{array}$ \\
\hline G.P.T. & $\begin{aligned} \mathbf{r}=0.6264 \\
\\
\mathbf{P}<0.001\end{aligned}$ & $\mathrm{~S}-\mathrm{Fe}$ & $\begin{array}{l}r=0.2111 \\
0.05<P<0.1\end{array}$ \\
\hline G.O.T. & $\begin{aligned} r= & 0.4426 \\
& P<0.001\end{aligned}$ & $\gamma$-GTP & $\begin{array}{c}r=-0.0153 \\
P>0.1\end{array}$ \\
\hline L.D.H. & $\begin{array}{r}r=0.1799 \\
\mathbf{P}>0.1\end{array}$ & Al-P & $\begin{array}{r}r=0.0007 \\
\mathbf{P}>0.1\end{array}$ \\
\hline Z.T.T. & $\begin{array}{r}r=-0.018 \\
P>0.1\end{array}$ & LAP & $\begin{array}{r}r=0.0920 \\
\mathbf{P}>0.1\end{array}$ \\
\hline T.T.T. & $\begin{array}{r}\mathbf{r}=-0.066 \\
\mathbf{P}>0.1\end{array}$ & ChE & $\begin{array}{r}r=0.0684 \\
P>0.1\end{array}$ \\
\hline
\end{tabular}

薬剤性肝炎による肝内胆汁万っ湍 3 例，胆石，腫瘍の 肝転移および cholangioma による肝外性胆汁らっ滞 6 例について黄疸発現よりの経過を見ると，肝内性胆汁 らっ滞では 1 例で S-ADH の上昇を見たが，他の 2 例で S-ADH 活性は低かった。 肝外性胆汁らっ濛では胆石の 


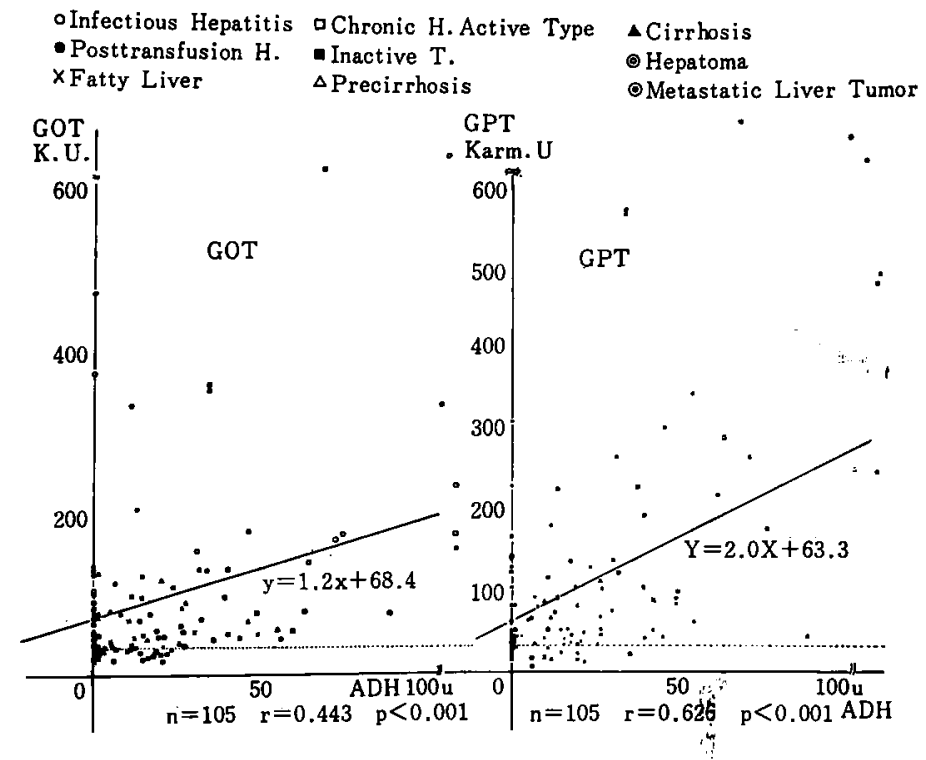

Fig. 10.

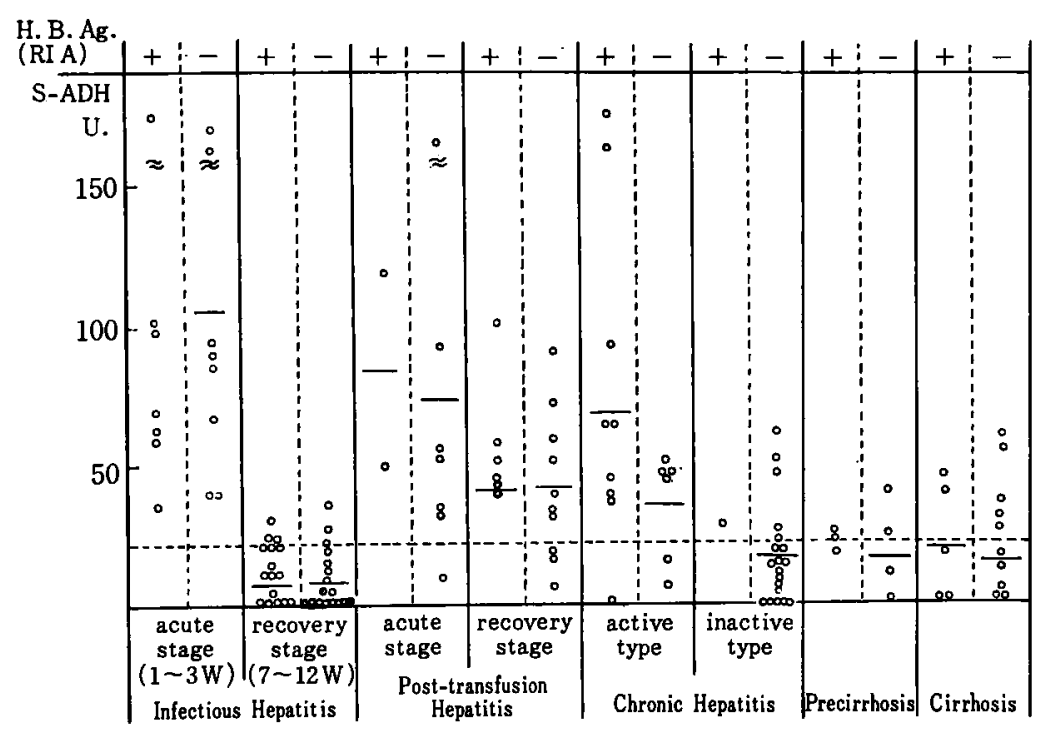

Fig. 11. S-ADH Relation to HB-Ag in Hepatic Diseases

2 例に初期に S-ADH の上昇を見たが他は正常值であ り，腫瘍の肝転移， cholangioma では末期にも S-ADH の上昇は少なかった。

\section{S-ADH と肝機能検查との関係}

S-ADH と肝機能との相関を見ると，GOT，GPT とは とるに $\mathrm{P}<0.001 て ゙$ 有意の相関があり（Fig. 10）, S-Fe
とは0.05<P<0.1で相関の傾向が見られ，肝実質細胞 障害との関係を示唆した. その他の T. Bil, BSP, LDH などとは相関がなかった（Table 3)。

肝疾患を R.I. 法により H.B.Ag の (十) と (一) に 分け, S-ADH との関係を見ると，慢性肝炎活動型では HB-Ag (十) の S-ADH $か ;$ HB-Ag (一) の S-ADH よ 
Table 4. S-ADH Relation to Histological Findings (32 Cases)

\begin{tabular}{|c|c|c|c|c|}
\hline Acinal Reconstruction & $\mathbf{r}=0.1554$ & $\mathbf{P}>0.1$ & Liver Cell Necrosis & $r=0.3144 \quad 0.1>P>0.05$ \\
\hline Fibrosis & $\mathbf{r}=0.2550$ & $\mathbf{P}>0.1$ & Eosinophilic Body & $r=0.1967 \quad P>0.1$ \\
\hline $\begin{array}{l}\text { Cell Infiltration in Portal } \\
\text { Areas }\end{array}$ & $\mathbf{r}=0.2610$ & $\mathbf{P}>0.1$ & Ballooning & $r=-0.1414 \quad P>0.1$ \\
\hline $\begin{array}{l}\text { Destruction of Limiting } \\
\text { Plate }\end{array}$ & $\mathbf{r}=0.2416$ & $\mathbf{P}>0.1$ & Fatty Infiltration & $\mathbf{r}=0.3169 \quad 0.1>\mathrm{P}>0.05$ \\
\hline Hypertrophy of Liver Cells & $\mathbf{r}=0.1729$ & $\mathbf{P}>0.1$ & Vacuolisation of Nuclei & $\mathbf{r}=0.1742 \quad \mathbf{P}>0.1$ \\
\hline \multirow[t]{2}{*}{$\begin{array}{l}\text { Mobilization of Kuppfer's } \\
\text { Cells }\end{array}$} & $r=0.6246$ & $\mathbf{P}>0.001$ & Biliary Stasis & $\mathbf{r}=-0.0736 \quad \mathbf{P}>0.1$ \\
\hline & & & $\begin{array}{l}\text { Proliferation of Bile } \\
\text { Ductules }\end{array}$ & $\mathrm{r}=-0.0421 \quad \mathrm{P}>0.1$ \\
\hline
\end{tabular}

ク0. 05<P<0.1で高い傾向にあった（Fig. 11）.

6. S-ADH と肝組鐡所見との閶係 (Table. 4)

急性肝炎 5 例, 慢性肝炎 14例, 前硬变 5 例, 肝 硬变 5 例, アルコール性肝障害 3 例, 計32症例につ いて S-ADH と肝組穖との相関を見ると, 星細胞動員で $P<0.001$ と有意に相関があり, 次いで肝細胞壊死, 脂 肪浸潤で 0.1>P>0.05と相関の傾向があり, 肝機能 と併せて S-ADH は肝実質障害と関連が深いと考えられ た.

\section{考按}

$\mathrm{ADH}$ はアルコール代謝の律速酵素として肝 $\mathrm{ADH}$ を 中心に研究されて来たが(6)，一方ミクロゾームのエタ， 一ル代謝系 (MEOS) も重視されて来た7). 実験的に ラットにフルコールを投与すると肝 $\mathrm{ADH}$ 活性は上昇す るが,アルコール多领者では肝 $\mathrm{ADH}$ 活性は減少すると いわれる8).

肝細胞障害時血中へ逸脱して S-ADH が検出されるが， その臨床的考察は少なく"-11)，その意義む確立してい ない.

$\mathrm{ADH}$ の臓器分布は大多数肝にあり, 少量は胃, 腸, 督，脳などに存在し，肝細胞内分布は約 $80 \%$ 上清成分 にあるといわれている(2).

人種的に欧米人の ADH は至適 $\mathrm{PH} 10.8$ 多く,アフ リカゃアジア人では pH 8.5の atypical ADH が多いと いわれ, アルコール処理能を, 両者を用いて人類学的に 究明しようとの試みあある ${ }^{13,14)}$.

F S-ADH の測定には，基質にェタノールを用いNAD $\rightarrow$ NADH の変化を測定する方法 ${ }^{15)}$ と， アセトアルデヒド を基質に用いて $\mathrm{NADH} \rightarrow \mathrm{NAD}$ の変化を測定する方法が あるが9, アセトフルデヒドは沸点が低く、エタノール の方が取り报いやすいと思われる.
健康人では ADH 活性は 0 または低值で,16) , 我々は 0〜22Uを正常值とした. 我くの 1 単位 $(\mathrm{m} \mu \mathrm{mole} / \mathrm{m} l / \mathrm{hr}$.) は国際単位 (I.U.) ( $\mu . \mathrm{mole} / \mathrm{L} / \mathrm{min}$.$) の / 60$ 倍に当る ${ }^{17}$.

S-ADH は肝疾患では急性肝炎初期および極期に著明 な上昇を見，以後速やかに正常化し，慢性肝炎，肝硬 変，肝癌ではほとんど上昇しないが，急性増悪時に上舁 を見るといら報告”がある．我々の結果です S-ADH は 急性肝炎の急性期に高值を示し，回復期では流行性肝炎 では速やかに正常化したが，輸血後肝炎では持続的上昇 を示す例が多かった．これは輸血後肝炎が流行性肝炎よ り要延しやすいことによると思われる。

慢性肝炎活動型では非活動型に比し有意に S-ADH か; 高く，持続的に高值を示寸症例が多かったが，肝実質炎 症の持続による肝細胞の変性壊死を示すと考えられる.

肝硬変では肝 $\mathrm{ADH}$ 活性は低く ${ }^{18)}$, アルコール代謝 る低下しており ${ }^{19)}$ ，肝実質の炎症の少ない代償期では S-ADH 活性上昇は少なく，今回は代償期 9 例，非代幎 期 2 例で，とすに S-ADH の平均値は正常域にあった.

肝腫晹では，肝転移により肝実質障害を起こし， S$\mathrm{ADH}$ の著明な上昇を見るとさああるといわれる ${ }^{16\rangle}$. 我 々の見た原発性および亮発性肝癌 7 例では, 肝実質障害 が充分考えられたが，要ADH の著明な上昇を見なかっ た. しかし最近経験した肝硬变合併肝癌の 1 例では，末 期肝珄昏睡を起こした時点に 230.6Uといら高值を示し た.このことからさらに症例を重ねて検討する必要があ 万.

ADH を少量含む胃，啺，留などの疾患，脺および胆 道疾患に S-ADH の上昇は少なく，S-ADH の上昇は肝 疾患に特異的と考光られた。

アルコール多飲者 ${ }^{5)}$ では S-ADH は上昇を示さない例 が多く,とくにアルコール性肝硬変では肝 ADH む減少 


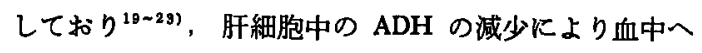
の逸脱は少ないと考えられた.

流行性肝炎回復期の平均正常化日数は S-ADH は33日 で S-GOT 48日，S-GPT 52日より早かったが，S-ADH は発症後 7 日でピークに達し，21日で血中より消失する との報告2)と同傾向を示した.

慢性肝炎活動型と非活動型を肝機能異常より鑑別が試 みられてきたが，我々のデーターでは S-ADH は TTT とともに活動型に有意に異常の見られる傾向があり，両 者の鑑別での役割が期待される.

Mezey ${ }^{16)}$ は肝内胆汁らっ滞では肝細胞壞死を伴い， S-GOT, S-GPT の軽度上昇にるかかわらず S-ADH は 高值を示し, 肝外性胆汁らっ滞では肝細胞壊死を伴いに くく，S-ADH の上昇は見られないとし，両者の鑑別に S-ADH の有用性を述ぺている.これは ADH は肝細胞 壊死により初期に血中に出, 以後しだいに胆汁中に排泄 されるこど0，および四塩化炭素による肝障害を起こし たラットと末処理ラットを用い,ともに胆道を結禁し， 前者に S-ADH の高値を見たが，後者にはS-ADH の上 昇を見ないことをあげている16)，我国です閉塞性黄疸の 初期に S-ADHを用い, 肝内性就よび肝外性胆汁うっ滞 の鑑別の有用性を述べる報告 ${ }^{10}$ すある. 我々の研究結果 では，薬物性肝障害の一例に発症初期に S-ADH の高値 を示したが他の 2 例では S-ADH は正常值にあった，ま た肝外性胆汁らっ滞では胆石の 2 例で初期一時 S-ADH が上昇したが，他の 4 例で S-ADH の上昇は見て扰ら ず,この点す今後さらに検討する必要があると思われ る.

S-ADH は肝機能では GOT, GPT と有意の相関を認 め, S-Fe とも相関傾向を認めたが, 実験的に ADHは Omithine Carbamyltransferase ${ }^{25}$, Sorbitol Dehydrogenase 26) と類似の動態を示し，GOT，GPT，LDH とは異なる といら ${ }^{16)}$. 我々の結果は, 臨床的に肝機能では肝細胞障 害を反映するるのとよく相関し，肝組織所見の結果と合 わせて考察すると，肝細胞壊死との関保がより深いと考 えられた。

\section{耛語}

1） S-ADH は正常者では活性は低く正常値は $3.7 \pm$ 8.9 Uであり, 肝以外の ADH を含む臟器の疾患におい ても正常籁用内の值を示した.

2) 急性肝炎では S-ADH は GOT, GPT と平行して 動くが，流行性肝炎飞怙いてはT.A. より早く正常化 し，腀血後肝炎では持続的上昇を示す例が多かった。
3）慢性肝炎活動型では非活動型に比し有意にS-ADH が高く，持続的に高值を示例が多く両者の鑑別の補助 的方法の1つとして有用と思われた。

4) 脂肪肝, 前硬変, 肝硬変および肝腫汮, アルコー ル多飲者では正常値を示す症例が多かった。

5）閉塞性黄㡺では，肝内性於よび肝外性胆汁うっ滞 ではS-ADH の持続上昇を見る症例は少なかった。

6) S-ADH は GOT, GPT と有意に相関し, S-Fe と は相関する傾向を示した．また肝組織所見では肝細胞壊 死と相関の傾向が見られた.

\section{文 献}

1) Sund, H. \& Theorell, H.: The Enzymes, Vol. 7, Academic Press, New York and London, 1963, p 25.

2) Bonnichsen, R.K. \& Brink, N.G.: In Methods in Enzymology, Vol. 10, 1st Edited by S.P. Colowick and N.O. Nathan, Academic Press, New York, 1955, p 495.

3) Krebs, H.A. \& Perkins, J.R.: The physiological role of liver alcohol dehydrogenase. Biochem. J., 118: 635, 1970.

4) Ferguson, M.M.: Observations on the histochemical distribution of alcohol dehydrogenase. Quart. J. Micr. Sci., 106: 289, 1965.

5) 滝野辰郎, 結城武彦ら:アルコール多飲と肝障 害の臨床的研究. 肝臓, $15: 18,1974$.

6) 藤沢 洌：フルコール性肝障害: 医学のあゆ み, $86: 1105,1973$.

7) Lieber, C.S.: Metabolic changes induced by alcohol, Edited by G.A. Martini and Ch. Bode, Springer-Verlag, Berlin. Heidelberg. New York, 1971, p 85.

8) Popper, H. \& Schaffner, F.: Progress in Liver Diseases II, Grune \& Stratton, New York and London, 1965, p 145.

9）浜向賢司：血清フルコール脱水素醭素活性につ いての実験的並びに區床的研究. 日消会誌, 58 : $1297,1961$.

10）原田俊則, 西村秀男ら：肝疾患時の血清てルコ 一ル脱水素醉素の検討, 肝臓, $11: 434,1970$,

11) Wolfson, S.K. Jr. \& Spencer, J.A. et al.: Clinical and experimental studies on serum pyridine nucleotidelinked dehydrogenase in 
liver damage, Ann. N.Y. Acad. Sci., 75: 260, 1958.

12) Nyberg, A., Schuberth, J. et al.: On the intra cellular distribution of catalase and alcohol dehydrogenase in horse, guinea pig and rat liver tissues. Acta Chem. Scand., 2: 1170, 1953.

13) Popper, H. \& Schaffner, F.: Progress in Liver Diseases. Grune \& Stratton, New York and London, 1972, p 549.

14) Edwards, J.A. \& Price Evans, D.A.: Ethanol metabolism in subjects possessing typical and atypical L-ADH. Clin. Pharm. Therap., 8: 824, 1967.

15）島 未明, 坪倉篤雄 : 人肝荿および血清 Alcohol Dehydrogenase 活性測定法. 臨床病理, 19 : 376, 1971.

16) Mezey, E. \& Cherrick, G.R. et al.: Serum alcohol dehydrogenase, an indicator of intrahepatic cholostasis. New Engl. J. Med., 279: 241, 1968.

17) Karger, S.: Einfurung in die Praktische Biochemie Basel, Schweiz., 1965, p 305.

18）大谷隆雄 : 肝障害時のアルコール代謝に関する 研究. 阪大医誌, $11: 2529,1959$.

19) Danopoulos \& Maratos, K. et al.: Studies on the alcohol's metabolism in patients with atrophic liver disease, Acta Med. Scand., 8:
$485,1954$.

20) Figueroa, R.B. \& Klotz, A.P.: Alterations of liver alcohol dehydrogenase and other hepatic enzymes in alcoholic cirrhosis. Gastroenterology, 43 : 10, 1962.

21) Asada, M. \& Galambos, J.T.: Liver disease, hepatic alcohol dehydrogenase activity and alcohol metabolism in the human, Gastroenterology, 45: 67, 1963.

22) Mezey, E. \& Tobon, F.: Rates of ethanol clearance and activities of the ethanol oxidizing enzymes in chronic alcoholic patients, Gastroenterology, 61: 707, 1971.

23) Ugarte, G. \& Pino, M.E. et al.: Hepatic ADH in alcoholic addicts and without hepatic damage, Amer. J. Dig. Dis., 12: 589, 196:

24) Mezey, E. \& Cherrick, G.R. et al.: Biliary excretion of alcohol dehydrogenase, J. Lab. Clin. Med., 71 : 798, 1968.

25) Reichard, H.: Ornithine carbamyl transferase activity in human serum in diseases of liver and biliary system. J. Lab. Clin. Med., 57: 78, 1967.

26) Asada, M. \& Galambos, J.T.: Sorbitol dehydrogenase and hepatocellular injury: experimental and clinical study. Gastroenterology, 44: 578, 1963.

\title{
A Clinical Study on Serum Alcohol Dehydrogenase in Liver Diseaeses
}

\author{
Takino Tatsuro, Yukı Takehiko, Kawamura Haruo, Tớyoda Eichi, \\ Sakanaka Toshio, Takamori Shigeyuki, Takahashi Tokindo, \\ Kanatsuna Takahiro \& Masuda Masasuke*
}

Serum alcohol dehydrogenase (S-ADH) was determined in 108 patients with liver diseases, in 41 patients without liver disease as well as in 17 alcoholics.

The clinical significance of $\mathrm{S}-\mathrm{ADH}$ results from the following:

1. S-ADH activity was low in normal adults and in group of non hepatic diseases.

2. In acute infectious hepatitis, S-ADH activity paralleled to S-GOT and S-GPT and 
returned to normal earlier than transaminase.

3. In the active type of chronic hepatitis S-ADH was significantly higher than in the inactive type and continuously raised. Therefore measurement of S-ADH may be useful for the differencial diagnosis between active type and inactive type of chronic hepatitis.

4. In the intrahepatic cholestasis continuous elevation of S-ADH could not be found.

5. In alcoholics $\mathrm{S}-\mathrm{ADH}$ was within the normal range.

6. S-ADH determined here, showed atypical $\mathrm{ADH}$.

7. In general, S-ADH activity had intimate correlation to elevation of serum transaminase which tends histologically to present the necrosis of liver cells.

*Third Department of Internal Medicine Kyoto Prefectural University of Medicine (Kyoto) 